\title{
Individual variability of venom from the European adder (Vipera berus berus) from one locality in eastern Hungary
}

Tamás Malina ${ }^{a *}$, László Krecsák ${ }^{\mathrm{b}}$, Alexander Westerström ${ }^{\mathrm{c}}$, Gábor Szemán-Nagy d, Gyöngyi Gyémánt ${ }^{\mathrm{e}}$, Márta M.-Hamvas ${ }^{\mathrm{f}}$, Edward G. Rowan ${ }^{\mathrm{g}}$, Alan L. Harvey ${ }^{\mathrm{g}}$, David A. Warrell $^{\text {h }}$, Balázs Pál ${ }^{\mathrm{i}}$, Zoltán Rusznák ${ }^{\mathrm{i}}$, Gábor Vasas f,j

${ }^{a}$ Pfizer Hungary Ltd., Medical Division, Alkotás u. 53, H-1123 Budapest, Hungary.

${ }^{\mathrm{b}}$ Quintiles, Hungarian Head Office, Regulatory Affairs, Budafoki út 91, H-1117 Budapest, Hungary.

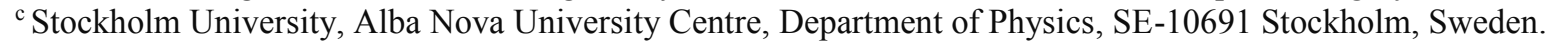

${ }^{\mathrm{d}}$ University of Debrecen, Department of Cell Biology and Molecular Biology, Egyetem tér 1, H-4010 Debrecen, Hungary.

${ }^{\mathrm{e}}$ University of Debrecen, Department of Inorganic and Analytical Chemistry, Egyetem tér 1, H-4032 Debrecen, Hungary.

${ }^{\mathrm{f}}$ University of Debrecen, Department of Botany, Faculty of Science and Technology, Egyetem tér 1, H-4010 Debrecen, Hungary.

${ }^{g}$ Strathclyde Institute of Pharmacy and Biomedical Sciences, University of Strathclyde, 161 Cathedral Street, Glasgow G4 0RE, United Kingdom.

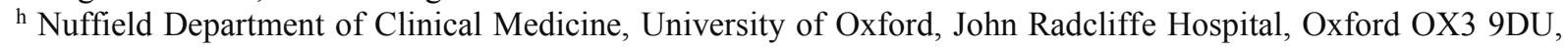
United Kingdom.

${ }^{\mathrm{i}}$ University of Debrecen, Medical and Health Science Centre, Department of Physiology, Nagyerdei Krt. 98, H4012 Debrecen, Hungary.

j CETOX - Analytical and Toxicological Research and Consultant Ltd., Egyetem tér 1, H-4032 Debrecen, Hungary.

\begin{abstract}
We have revealed a remarkable degree of intra-population variability among several individual venom samples from the European adder (Vipera berus berus) within a defined population in eastern Hungary. There was significant variation in venom protein profiles, both gender-specific and age-related, using one-dimensional electrophoresis and gelatinzymography. There was obvious interspecimen variability in phospholipase $A_{2}$ activity, phospholipase $\mathrm{A}_{2}$-spectra (using MALDI-TOF MS based on molecular weights of components), and toxicity assays ( $\left.\mathrm{LD}_{50}\right)$. Venom samples had variable neuromuscular paralysing effects on chick biventer cervicis nerve-muscle preparations. The relevance of variable venom yields is discussed. The data suggest that individual venom variation among $V$. b. berus living in eastern Hungary might contribute to the wide range of clinical manifestations in envenomed patients, notably neurotoxicity, that is not typical of $V$. b. berus envenoming elsewhere in Europe.
\end{abstract}

Keywords: neurotoxic; phospholipase $\mathrm{A}_{2}$; protease; venom variation; Vipera berus berus

*Corresponding author: T. Malina; E-mail address: tamas.malina80@gmail.com Tel.: +36/30/4752109; postal address: Pfizer Hungary Ltd., Medical Division, H-1123 Alkotás u. 53 Budapest, Hungary

\section{Introduction}

The common adder ( $V$. berus), which is the most widely distributed Vipera species causes many cases of snake-bite envenoming throughout Northern and Central Europe. It is represented by the nominate subspecies $(V . \quad b$. berus $)$ in most parts of the continent (Ursenbacher et al., 2006). Vipera berus is the only indigenous viper in United Kingdom, Sacndnavian countries, Netherlands, Belgium, Luxembourg and Poland. In Hungary, $V . b$. berus is the sole clinically significant native venomous snake, mainly occurring in three separated regions: the Zemplén Hills and Eperjes-Tokaj Range in the Northeast, the Upper Tisza Valley in the East, and Somogy and Zala counties in the Southwest. 
Intraspecies variation in venom composition is of scientific interest for reasons of ecology, taxonomy/evolution, clinical manifestations of envenoming and epidemiology of snake-bites, and design and production of antivenom (Casewell et al., 2014). Regional differences in venom composition have been shown within some populations of the longnosed viper ( $V$. ammodytes) (Balija et al., 2005) and asp viper (V. aspis) (Ferquel et al., 2007). Individual variability in venom composition within dicrete snake populations (intrapopulation differences) are known for Lataste's viper ( $V$. latastei (Arez et al., 1994)) and $V$. ammodytes (Master and Kornalík, 1965). Significant individual differences have been detected in the phospholipase $\mathrm{A}_{2}\left(\mathrm{PLA}_{2}\right)$ content of venom within a south-eastern French $V$. aspis population (Ferquel et al., 2007). More recently, age-dependent venom variation was described in $V$. ammodytes and the Caucasus viper (V. kaznakovi) in Turkey (Arikan et al., 2014).

Although the venom of $V$. berus has been extensively studied in the past 20 years, the main venom characteristics in different localities and populations remain unknown. Most studies involved $V . b$. berus from Russian and France (Guillemin et al., 2003; Malenev et al., 2007; Ramazanova et al., 2008; Latinović et al., 2016), while one used $V$. berus venom from former Czechoslovakia (Mebs and Langelüddeke, 1992). These $V$. b. berus venoms contained oedema-forming, anti-haemostatic, anticoagulant, fibrinolytic, proteolytic, haemorrhagic and myotoxic components (Saint Girons and Detrait, 1978; Mebs and Langelüddeke, 1992; Calderón et al., 1993; Samel et al., 2003; Latinović et al., 2016). There have been few studies of variations in $V$. berus venom composition. However, Nedospasov and Rodina (1992) described age-related variations in amidolytic activity of $V$. b. berus venoms, Malenev et al. (2007) showed variations in venom LD50 between $V$. b. berus populations in different Russian localities, and Zaitseva (2011) investigated regional variations in Russian V. berus venom composition in the Volga basin.

The aim of the present study was to investigate variation in venom yield and composition among samples from individual specimens from the same $V$. $b$. berus population in eastern Hungary, in the hope of better understanding unusual clinical manifestations in envenomed patients.

\section{Materials and methods}

\subsection{Collection and storage of venom}

Venoms from healthy $V$. b. berus specimens of both sexes were milked in the field, very soon after capture in eastern Hungary between 2008 and 2011. All venoms were collected during mid-spring in order to avoid possible seasonal changes in venom composition. Individual, not pooled, venom samples were used to investigate the individual venom variability (Chippaux et al., 1991). Glass capillaries, Pasteur pipettes or manual gland massage were used for milking, depending on the size of specimens, following induced strike on Eppendorf tubes. Total lengths were recorded and the snakes were then released. Venoms samples were flash frozen in liquid nitrogen in the field. Each venom was lyophilized in the laboratory, its dry weight was measured and it was then stored in dark at $-80^{\circ} \mathrm{C}$ until used. Two venoms were used as control: one was collected from an adult $V$. $b$. berus specimen (of unknown gender) in the Ybbs Mountain of eastern Austria in May 2006; the other was from an adult Nikolsky's adder ( $V$. nikolskii) (gender unknown) from Pidlisne, central Ukraine, collected in early May 2009. Statistical significance was determined using z-test with twotailed distribution and two-sample equal variance at $95 \%$ confidence interval.

\subsection{Limitations}

Vipera berus is a relatively small species with a lower venom yield compared to other European viperids (i.e. $V$. ammodytes, $V$. latastei). 


\subsection{Protein content determination and one-dimensional Sodium dodecyl sulfate-}

polyacrylamide gel electrophoresis (SDS-PAGE)

Protein concentration was determined by the method of Bradford (1976) using bovine serum albumin (BSA) as the standard. Absorbance was measured at $595 \mathrm{~nm}$. In order to estimate the molecular mass of the proteins, the individual crude venoms were initially separated by SDS-PAGE, in a discontinuous gel and buffer. The resultant pellets were dissolved in the sample buffer and the electrophoresis was performed on 10 to $18 \%$ linear sodium dodecyl sulfate (SDS)-polyacrylamide gradient gels as described previously (Laemmli, 1970). Marker proteins (used for quantification of molecular weight of the venom) were included in the runs and the gels were stained with coomassie blue and subsequently analysed using UVIDoc software (UVI, Cambridge, UK). For statistical analysis of SDSPAGE the band obtained for the individual samples have been grouped into eight groups, as follows: juvenile female $(n=2)$, juvenile male $(n=3)$, subadult female $(n=4)$, subadult male $(\mathrm{n}=5)$, adult female $(\mathrm{n}=8)$, adult male $(\mathrm{n}=3)$, plus the control samples of $V$. b. berus from Austria $(\mathrm{n}=1)$ and $V$. nikolskii $(\mathrm{n}=1)$. Bands presence $(1)$ and absence (0) were scored. Hierarchical clustering, Unweighted Pair-Group Method on group average (UPGMA) using Jaccard 's similarity coefficient, was run using the SYN-TAX 2000 program package (Podani, 2001). In order to determine the congruence between the dendrogram and the underlying resemblance matrix, the cophenetic correlation coefficient $\left(r_{c s}\right)$ was also calculated.

\subsection{Matrix-assisted laser desorption/ionization time-of-flight mass spectrometry (MALDI- TOF MS)}

MALDI-TOF MS is a suitable analytical tool in the detection and direct measurement of molecular weights of components in crude snake venoms (Favreau et al., 2006). MALDITOF MS measurements of the individual crude venoms were carried out in linear mode using a Bruker Biflex III mass spectrometer (Bruker Daltonik GmbH, Bremen, Germany). External calibration was applied using the $[\mathrm{M}+\mathrm{H}]^{+} \mathrm{m} / \mathrm{z}: 12361.1971$ and $[\mathrm{M}+2 \mathrm{H}]^{2+} \mathrm{m} / \mathrm{z}: 6181.1023$ peaks of Cytochrome c as calibrants. Sinapinic acid (3,5-dimethoxy-4-hydroxacinnamic acid) was the matrix solution at final concentration of $20 \mathrm{mg} / \mathrm{ml}$ using $0.1 \%$ trifluoroacetic acid (TFA) solution in water: acetonitrile 2:1 as solvent. The venom was dissolved in $200 \mu \mathrm{l}$ of 0.1 $\%$ TFA and a $10 \mu \mathrm{l}$ sample plus $15 \mu \mathrm{l}$ of matrix solution were mixed and $0.5 \mu 1$ was applied to the target plate and allowed to dry at room temperature. Spectra from multiple (at least 100) laser shots $\left(\mathrm{N}_{2}\right.$ laser, $\left.337 \mathrm{~nm}\right)$ were averaged prior to analysis. Samples analysed four times to check the accuracy and reproducibility of the results; the average variance is maximally $5 \mathrm{Da}$ in each molecular mass range. Statistical significance was determined using z-test with twotailed distribution and two-sample equal variance at $95 \%$ confidence interval.

\subsection{Phospholipase $\mathrm{A}_{2}$ activity assay}

Phospholipase $\mathrm{A}_{2}\left(\mathrm{PLA}_{2}\right)$ activity of the venoms was determined by the method of Santoro et al. (1999). Briefly, venoms were diluted in $1 \mathrm{~mL}$ cold $\left(4^{\circ} \mathrm{C}\right) \mathrm{PBS} \mathrm{pH} 7.4$, and $1 \mu \mathrm{g}$ protein was added to $1.5 \mathrm{~mL}$ of reaction solution $(100 \mathrm{mM} \mathrm{NaCl}, 10 \mathrm{mM} \mathrm{CaCl}, 7 \mathrm{mM}$ Triton $\mathrm{X}-100,0.265 \%$ soybean lecithin, $98.8 \mathrm{mM}$ phenol red, $\mathrm{pH} 7.6$ ) in a spectrophotometer cuvette. The solution was immediately homogenized and read at $558 \mathrm{~nm}$ (at room temperature). The definition of $1 \mathrm{U}$ of PLA 2 activity was taken as the amount of venom (mg of protein/assay) producing a decrease of 0.001 absorbance units per minute under the conditions described. $\mathrm{PLA}_{2}$ activity was expressed as U/mg of two independent experiments. Statistical analysis on $\mathrm{PLA}_{2}$ activity was performed on MATLAB Version 8.4.0.150421(R2014b) using Two-way ANOVA to test for differences in the mean of sample populations belonging to groups 'sex' (with categories: 'male' and 'female') and age (with categories 'juvenile', 'subadult' and 'adult'). 


\subsection{Protease activity/substrate zymography}

Gelatin-zymography can be applied to evaluate protease activities of venoms (Hasson et al., 2004; Malta et al., 2008). For the determination of proteolytic activity of venoms, samples were homogenized with $100 \mathrm{mM}$ Tris-HCl buffer $\mathrm{pH} 8.0$ (Sigma-Aldrich) containing $150 \mathrm{mM} \mathrm{NaCl}$ (Reanal, Budapest, Hungary) to final concentrations of $5 \mathrm{mg} / \mathrm{ml}$ (Hasson et al., 2004). The homogenates were sonicated and shaken to disintegrate remaining organelles as described by Schlereth et al. (2000). After centrifugation (13.000×g, $2 \times 5 \mathrm{~min}$, Biofuge), the supernatants were used as crude protein extracts. Protease activity analysis of samples (10-20 $\mu 1$ of $22 \mu \mathrm{g}$ protein) was carried out using gelatin-containing SDS slab gels according to Hasson et al. (2004) and Malta et al. (2008). Samples were mixed with equal volumes of protein loading buffer lacking $\beta$-mercaptoethanol and loaded on 10\% SDS-polyacrylamide gels containing $0.04 \%$ gelatin. The gels were run at $20 \mathrm{~mA} / \mathrm{gel}$ at $4{ }^{\circ} \mathrm{C}$ in the dark. To renature venom proteolytic enzymes, SDS was removed from gels by three 10 min washes in $2.5 \%$ $(\mathrm{v} / \mathrm{v})$ Triton X-100 in reactivating buffer. The gels were then incubated overnight at $37{ }^{\circ} \mathrm{C}$ in reactivating buffer $\left(50 \mathrm{mM}\right.$ Tris- $\mathrm{HCl} \mathrm{pH} 8.0,5 \mathrm{mM} \mathrm{CaCl}_{2}, 10 \mathrm{ng} \mathrm{NaN}$ ) in dark (Hasson et al., 2004). Local gelatin degradations were visible after Coomassie Blue staining (Coomassie Brilliant Blue R250) and revealed the sites of proteases with gelatinolytic activities.

\subsection{Determination of venom toxicity $\left(L D_{50}\right)$}

Toxicity was assessed as described previously by Theakston and Reid (1983) on Swiss-Webster male mice ( $\mathrm{n}=6$ /group). Four individual venoms were randomly chosen from the Hungarian adder population and tested together with the control samples $(n=2)$. The dose range of venoms was the following: $1.0 ; 0.8 ; 0.7 ; 0.6 ; 0.5 ; 0.4 ; 0.3$; and $0.25 \mu \mathrm{g} / \mathrm{g}$ i.v. Control mice $(n=6)$ were injected with normal (venom free) saline solution. LD $\mathrm{D}_{50}$ calculation was performed by probit analysis using Minitab 16 software. Distribution fitting was tested using Person's goodness-of-fit test. Additionally, pairwise relative potency tests have been performed to compare the $\mathrm{LD}_{50}$ fiducial estimated toxicity between each pair of samples. Experiments were authorised by the Committee of Animal Research of the University of Debrecen.

\subsection{Neuromuscular studies on chick biventer cervicis}

The chick biventer cervicis (CBC) preparation is sensitive to snake toxins and allows prejunctional effects to be distinguished from postjunctional ones (Harvey et al., 1994). The CBCs were removed from chicks which had been killed by exposure to $\mathrm{CO}_{2}$, and the preparations were set up as described previously by Harvey et al. (1994). Preparations were mounted under $1 \mathrm{~g}$ resting tension in $10 \mathrm{ml}$ glass organ baths containing Krebs-Henseleit solution with the following composition (mM): $\mathrm{NaCl}, 118.4 ; \mathrm{KCl}, 4.7 ; \mathrm{MgSO}_{4}, 1.2 ; \mathrm{KH}_{2} \mathrm{PO}_{4}$, 1.2; $\mathrm{CaCl}_{2}, 2.5 ; \mathrm{NaHCO}_{3}, 25$; and glucose, 11.1 . The solution was maintained at $37^{\circ} \mathrm{C}$ and continuously bubbled with $95 \% \mathrm{O}_{2} / 5 \% \mathrm{CO}_{2}$. Preparations were stimulated through the motor nerve via silver ring electrodes $(0.2 \mathrm{msec}$ pulses, voltage greater than required for maximal twitches at $0.1 \mathrm{~Hz}$ ), and responses were also obtained to sub-maximal concentrations of ACh $(1 \mathrm{mM})$, carbachol $(20 \mu \mathrm{M})$ and $\mathrm{KCl}(40 \mathrm{mM})$ before and after exposure to venom

\section{Results}

\subsection{Snakes and the amount of milked venom}

The studied lowland $V$. b. berus population lives in a limited area (mixed forest; Quercus robur - Fraxinus angustifolia subsp. pannonica - Carpinus betulus) in the Upper Tisza Valley up to an elevation of 100-150 m above the sea level. Specimens were collected on the edges of forest, woodland cuts, and edges of marshes. Overall 25 specimens were 
milked from the Hungarian adders: 11 males and 14 females, their total length was ranged from 16.2 to $77.4 \mathrm{~cm}$ (Table 1). The average total length was $50.7 \mathrm{~cm}$ (Males: 16.2-60.2 cm, average: $43.5 \mathrm{~cm}$. Females: $26.3-77.4 \mathrm{~cm}$, average: $56.5 \mathrm{~cm}$ ). According to their total length, adders were classified into three main approximate age-groups: i) juveniles $(n=5 ; 16.2-36.7$ $\mathrm{cm})$, ii) subadults $(\mathrm{n}=9 ; 42.5-50.7 \mathrm{~cm})$, iii) and adults $(\mathrm{n}=11 ; 58.3-77.4 \mathrm{~cm})$.

Dry weight of the milked venoms varied between 0.8 and $15.7 \mathrm{mg}$ (average was 5.7 $\mathrm{mg}$ /specimen), while it was $2.0 \mathrm{mg}$ in $V$. nikolskii and $6.3 \mathrm{mg}$ in the Austrian $V . b$. berus. Of the Hungarian adders, the average dry weight of venom was $4.7 \mathrm{mg}$ in males and $6.6 \mathrm{mg}$ in case of females. The difference was statistically insignificant between the genders (Pvalue $=0.3399$, at $95 \%$ confidence interval, 2 -tailed). The average dry weight of venoms was the following in the given age-groups: i) juveniles: $1.9 \mathrm{mg}$, ii) subadults $4.1 \mathrm{mg}$, and iii) adults: $8.9 \mathrm{mg}$. The difference was statistically significant between the juveniles and adults ( $\mathrm{P}$-value $=0.0057$, at $95 \%$ confidence interval, 2-tailed), and between the subadults and adults ( $\mathrm{P}$-value $=0.0227$, at $95 \%$ confidence interval, 2 -tailed). No significant difference was detected in the dry weight of venoms between the juvenile and subadult specimens ( $\mathrm{P}$-value $=0.4021$, at $95 \%$ confidence interval, 2-tailed).

\subsection{Comparison of the electrophoretic protein pattern of venom samples}

As determined by one-dimensional SDS-PAGE electrophoresis (non-reduced) (Fig. 1A), there is a clear variation in the number, the location, the abundance, and the intensity of protein bands among the individual venoms. The number of bands varies between 7 and 18 (average: 12.8) in the samples. Control samples presented 11 and 12 bands, respectively that showed the following molecular weights: 79, 62, 57, 45, 44, 42, 25.5, 18, 17, 16, $14 \mathrm{kDa}$ (Austrian $V$. b. berus) and 79, 62, 58, 45, 42, 40, 25, 19, 18, 17, 16, $13.5 \mathrm{kDa}$ ( $V$. nikolskii). The protein profile of $V$. nikolskii and the Austrian $V$. b. berus was different from the venom pattern of the Hungarian adders only in two protein bands (located in 57 and $41.5 \mathrm{kDa}$ ranges). The abundance and intensity of bands in the molecular mass range between 13 and $15 \mathrm{kDa}$ on the SDS-PAGE correspond to the expected PLA $\mathrm{P}_{2} \mathrm{~S}$ with a great predominance of proteins of molecular masses, indicated by their intensity and relative quantity. (Fig. 1A). These proteins were the dominant components of the Hungarian adder venoms and of the two controls, as well.

Major differences are notable in protein bands of individual venoms in the molecular mass range of 20-24 kDa, 30-40 kDa and 45-70 kDa. Individual analysis of the venom pattern of the Hungarian adders revealed a few gender-specific differences and similarities. There was no difference in the venom complexity associated with the number of protein bands between females $(n=14)$ and males $(n=11)$ : the average number of bands is 12 in males, while it is 11.9 in case of females. Four protein bands $(61,37,30$, and $21 \mathrm{kDa})$ were found in male venoms that were absent in female ones. On the other hand, there were three protein bands $(83.5,75,57.5 \mathrm{kDa})$ found only in the female adder venoms. Some age-related differences could be also observed on the electrophoretic profile of venoms. Only the venom pattern of juveniles contained bands with molecular weights of 37, 41, 59, 61 and $79 \mathrm{kDa}$; these bands were completely absent in the venom pattern of subadult and adult snakes. Venom pattern of subadults and adults is characterized by bands of molecular weights $27,34,44,66$, and 85 $\mathrm{kDa}$ that were not mirrored in the venom of juveniles. The dendrogram resulting from the UPGMA is showed in figure 1B. A cross line at the 0.82 dissimilarity level divided the dendrograms into three major groups: one contains the Austrian adder sample and the sample of $V$. nikolskii, while another contains the samples of juveniles, and a third group consists of the samples of subadult together with adult specimens. Our dendrogram had a cophenetic correlation of 0.93 , suggesting that the dendrogram provides an excellent representation of the resemblances. 


\subsection{Analysis of the phospholipase $A_{2}$ (PLA $)$ content of venoms by MALDI-TOF MS}

In order to assess the possible intra-population variations, the MALDI-TOF spectra of $\mathrm{PLA}_{2}$ content of all $(\mathrm{n}=25)$ the Hungarian adder venom samples and the two controls were compared. Unambiguous heterogeneity mirrored in the PLA 2 content of individual venoms in the molecular mass range between 13500 and $14400 \mathrm{Da}$; the detected molecular masses of components by MALDI-TOF-MS is shown by table 1 .

The Hungarian venoms gave from 4 to 7 peaks - depends on the specimens - in the molecular weights that vary between 13548 and $14340 \mathrm{Da}$. Five or six peaks were recorded in $72 \%$ of the samples. Of the Hungarian samples, the venom of females gave an average 5.1 peaks, while males gave 5.4 peaks between 13500 and $14400 \mathrm{Da}$; the difference was statistically insignificant between the genders (P-value $=0.8815$, at $95 \%$ confidence interval, 2-tailed). The average number of peaks in the different age-groups was the following: 4.4 in juveniles, 5.6 in subadults and 5.3 in adults. The difference was not significant between the different age-groups (juveniles-subadults: $\mathrm{P}$-value $=0.6668$; juveniles-adults: $\mathrm{P}$-value $=0.7386$; and subadults-adults: P-value $=0.8934$, at $95 \%$ confidence interval, 2-tailed). All the Hungarian samples contain component in the mass range between 13571 and $13587 \mathrm{Da}$. A very characteristic mass peak, which was the most intensive one, was identified at the range of $13800 \mathrm{Da}$ in $88 \%$ of the Hungarian adder venoms and only $16 \%$ of the Hungarian samples gave any peak in the molecular mass range of 13700 and 14200 Da. Representative spectra of venoms are shown in figure 2. Spectrogram of the control Austrian adder venom showed 5 peaks between 13550.03 and 14283.20 Da (Fig. 2). The other control venom, sample of $V$. nikolskii could be characterized by the presence of 3 peaks only (Fig. 2). In the Austrian $V$. $b$. berus sample, the most intense peak was also detected in the range of 13800, while it was at $13600 \mathrm{Da}$ in case of $V$. nikolskii. Of the 5 molecular mass peaks in the Austrian $V$. b. berus venom, there were two components with the same molecular masses (13893.93 and 14094.04 $\mathrm{Da}$ ) that were also identified in the venoms of the Hungarian adders, although, these were present only in two specimens. The venom of $V$. nikolskii did not contain any components detected with the same molecular mass in the range of $\mathrm{PLA}_{2} \mathrm{~S}$ as in the venoms of Hungarian snakes.

\subsection{Phospholipase $A_{2}\left(P L A_{2}\right)$ activity assay}

The total $\mathrm{PLA}_{2}$ activities of the individual venoms were also compared. Of the Hungarian specimens, the lowest activity was $385 \mathrm{kU} / \mathrm{mg}$, while the highest was $619 \mathrm{kU} / \mathrm{mg}$. Results are presented as mean \pm SEM: i) juveniles: $515 \mathrm{kU} / \mathrm{mg}( \pm 57)$, ii) subadults: 506 $\mathrm{kU} / \mathrm{mg}( \pm 61)$, and iii) adults: $492 \mathrm{kU} / \mathrm{mg}( \pm 54)$. The activity of individual samples differed from each other but no significant differences in population means were found in either groups $(\mathrm{p}=0.8582$ for sex-group, and $\mathrm{p}=0.8241$ for age-group), nor in group interaction $(\mathrm{p}=0.7773$ ). The control samples showed $546 \mathrm{kU} / \mathrm{mg}$ (Austrian V. b. berus) and $431 \mathrm{kU} / \mathrm{mg}$ (V. nikolskii), respectively.

\subsection{Protease activity assay/substrate zymography}

Clear and significant individual venom variations were detected on the zymograms using gelatine substrate (figure 3). Gelatinolytic activity could be observed in bands around 34-37, 45-50, and $60 \mathrm{kDa}$. Of 20 investigated venoms, certain samples (samples: 7; 11; 14; 15; 17; Fig. 3.) showed intensive gelatine-degradations around 34.7 and $45 \mathrm{kDa}$ on the substrate, while these were weakly observed between 45 and $70 \mathrm{kDa}$ in case of some venoms (samples: $8 ; 9 ; 10 ; 18 ; 19 ;$ Fig. 3.). Degradations could hardly or not been detected in a few Hungarian samples (samples: $12 ; 13 ; 16 ; 23$ ) shown in figure 3 . On the bases of the gelatinezymogram, the control Austrian $V$. $b$. berus venom had much lower enzymatic activity than 
that of the most Hungarian $V . b$. berus venoms. The venom of $V$. nikolskii was almost devoid of this type of activity demonstrated by our substrate zymography.

\subsection{Lethal toxicity ( $\left.L D_{50}\right)$ of crude venoms}

In case of all the tested Hungarian venom samples $(n=4$; their sex and age are shown by Fig. 4) envenoming resulted in characteristic signs on mice, i.e. head-drop and floppy neck, progressive respiratory paralysis preceded by initial increase in respiration rate and limb-paralysis prior to death from respiratory paralysis. Following administration of $0.80 \mu \mathrm{g} / \mathrm{g}$ i.v. to mice, these symptoms developed within circa $40 \mathrm{~min}$, and death followed 1-1.5 h after venom injection. All of the above-mentioned characteristic paralytic signs of envenoming were also visible on mice after the injection of $V$. nikolskii venom. While these were lacked in case of the maximum dose $(1.0 \mu \mathrm{g} / \mathrm{g}$ i.v.) of the Austrian $V$. b. berus sample, although, it was lethal in $100 \%$ in the given dose (after the injection of the Austrian venom, mice were able to move till the last moment, when the respiration had become irregular and very intensive directly prior to death). $\mathrm{LD}_{50}$ value of the most toxic sample was $0.41 \mu \mathrm{g} / \mathrm{g}$ i.v. (Fig. 4). The Log-logistic distribution fitted best for our data as revealed by the Person's goodness-of-fit test (Person $\chi^{2}=19.77, \mathrm{df}=27, \mathrm{p}=0.84$; Deviance $\chi^{2}=23.38, \mathrm{df}=27, \mathrm{p}=0.66$ ). The regression slopes equality among the venoms was not violated (Test for equal slopes $\chi^{2}=9.07731, \mathrm{df}=5$, $\mathrm{p}=0.106)$. The detected significant differences in $\mathrm{LD}_{50}$ values are presented on figure 4.

\subsection{Neuromuscular studies on chick biventer cervicis (CBC) nerve-muscle preparations}

In the first set of experiments, two Hungarian $V$. $b$. berus venom samples were randomly chosen and tested on isolated CBC nerve-muscle preparation (Fig 5). The Austrian $V$. b. berus venom was used as a control. All the three venom samples caused a slow progressive reduction in the height of the twitch response at $10 \mu \mathrm{g} / \mathrm{ml}$. There was some initial augmentation in preparations exposed to the Austrian $V$. b. berus. After 180 minutes in venom at $10 \mu \mathrm{g} / \mathrm{ml}$, twitch height was about $20 \%$ of control (pre-venom) height. Responses of the preparations to the exogenous agonists (acetylcholine, carbachol and $\mathrm{KCl}$ ) were tested after complete twitch block. There was little change in preparations exposed to the two Hungarian venoms (sample 23 and 20), while responses to all three stimuli were reduced in preparations exposed to the Austrian (sample 26) venom. At higher concentration, the reduction in twitch responses to indirect stimulation was faster than with $10 \mu \mathrm{g} / \mathrm{ml}$ and all preparations were completely blocked. Some preparations showed a small, slowly developing and slowly waning contracture during the onset of twitch block (not shown). Similar preparation responses were detected to the agonists after complete twitch block when the preparations were exposed to higher venom concentration, but responses to all the three stimuli were markedly reduced in preparation exposed to the Austrian venom sample at $30 \mu \mathrm{g} / \mathrm{ml}$. There was no recovery after wash-out of the venoms in each case (not shown).

In further experiments, more samples from the Hungarian venoms were randomly chosen and also tested on CBC nerve-muscle preparations (Fig 5). In this case, the control venom was $V$. nikolksii (sample 27). The venom concentration was $30 \mu \mathrm{g} / \mathrm{ml}$ and the twitch height was measured after 30 minutes and then, an additional $70 \mu \mathrm{g} / \mathrm{ml}$ was added (total venom concentration was $100 \mu \mathrm{g} / \mathrm{ml}$ ). The time to $50 \%$ block was recorded and after about 120 minutes total exposure, responses to acetylcholine, carbachol and potassium chloride were determined. All samples apart from one (sample: 13) reduced the twitch responses to nerve stimulation.

\section{Discussion}

Snake venoms are highly complex biologically active mixtures but their composition can be influenced by several extrinsic and intrinsic factors. These can affect their biochemical 
and pharmacological properties, resulting in intraspecific venom variations - between separate geographical populations and even within population that might have clinical implications (Ferquel et al., 2007; Casewell et al., 2014).

Significant individual differences were detected in the dry-weight of milked venoms in different approximate age-groups of the adders. Compared to published data on $V$. berus venom yields, our results most closely resembled data from Brown (1973), suggesting an average yield of $6 \mathrm{mg}$.

Our results show great individual variations, involving gender-specific and age-related differences in the venom protein profiles, demonstrated by non-reduced SDS-PAGE gel. Ontogenetic shift in diet is a plausible explanation for the differences in the venom composition between juvenile and adult adders. In many habitats, juveniles prefer lizards (genera Lacerta and Zootoca), whereas adults prefer small rodents (Nilson et al., 2005). However, venom composition at the individual level is influenced by genetic as well as environmental factors (Casewell et al., 2014). Perhaps dynamics of protein production and peptide maturation in juveniles differs from that in adults, contributing to variations in venom protein profiles.

There was also marked individual variability in molecular masses of components as detected by MALDI-TOF MS, corresponding to previously published molecular ranges of PLA $_{2}$ from the venoms of Vipera species (Jan et al., 2007). We suggest that the presence or absence of a given PLA 2 in the venoms of different individual snakes can be the result of differences in gene encoding, determined by ecological factors, as well as control of gene expression and/or gene frequencies within the same adder population where our venom samples were collected. PLA 2 spectra of Hungarian $V$. berus venoms resembled the Austrian $V$. berus control venom, but differed markedly from the $V$. nikolskii venom.

Total $\mathrm{PLA}_{2}$ and protease activity were chosen to characterization individual venoms biochemically. However, significant individual differences in PLA 2 activity were not observed, although variability was revealed in protease activity from different specimens. In this latter case, some specimens shared a conserved region of substrate degradation, while others were completely devoid of protease activity on the gelatine substrate. The degradation profile of venoms correlates with the detected variability in the venoms' electrophoretic protein expression profile, associating with the serine- and metalloproteinases, mainly in the range of 45-70 kDa. However, the venom of this taxon contains these proteases (Samel et al., 2003) that are primary responsible for causing oedema and bruising in envenomings by European Vipera (Persson, 2015). We suggest that the low or absent venom protease activity combined with the low average venom yield of the eastern Hungarian adders explains the mild local symptoms in patients bitten in this region (Malina et al., 2008, 2013).

In general, the venom of $V . b$. berus is thought to be devoid of neurotoxic activity (Križaj et al., 1993; Ramazanova et al., 2008; de Haro et al., 2009; Magdalan et al., 2010). However, cranial nerve involvement in humans envenomed by $V$. $b$. berus, have been documented sporadically in the early literature and, more recently (Table 2). Without exception these incidents derive from the Carpathian Basin. Evidence of neurotoxic activity of $V$. b. berus venom, using the chick biventer cervicis nerve-muscle preparation, was found in all but one sample of venoms from adders living in the region of Hungary where neurotoxic envenomings have been reported (Malina et al., 2008, 2013). The effects were consistent with block of ACh release of from the motor nerve terminals combined with minor effects on ACh receptors or directly on skeletal muscle in the Hungarian adder and $V$. nikolskii venom. The Austrian $V . b$. berus venom differed markedly from the Hungarian adder venoms and from $V$. nikolskii venom by reducing responses to all three postjunctional agonists, indicating a myotoxic effect. As far as snake taxonomy is concerned, these findings confirm that possession of venom neurotoxin by members of $V$. berus sub-species is not a reliable indicator 
of taxonomic sub-divisions (Ramazanova et al., 2008). Among European viper species, prejunctional block tends to be associated with venom PLA 2 content (Jan et al., 2007). However, all our studied samples, including the non-neurotoxic one, had many molecular species in the mass ranges of typical PLA ${ }_{2} \mathrm{~S}$, implying the presence of both toxic and nontoxic PLA $2 \mathrm{~S}$.

The high lethal toxicity of the Hungarian adder venoms in mice could be attributable to their prejunctionally-acting $\mathrm{PLA}_{2} \mathrm{~S}$, since $\mathrm{PLA}_{2}$-dependent skeletal neuromuscular junction specific neurotoxins are the most toxic venom components, which rapidly kill the prey, predominant by immobilizing them.

In summary, specimens of the investigated lowland $V . b$. berus population in a defined area in eastern Hungary have evolved variable venom phenotypes. Marked individual variability is reflected not only in their electrophoretic venom profile but also in the spectra of $\mathrm{PLA}_{2}$ content and certain enzymatic, pharmacological and biological activities. Our results illustrates that these adder venoms consist of a mixtures of multiple toxic components including neurotoxins - which show remarkable individual variability combined with an average low venom yield. As a result, it is not surprising that envenomed humans occasionally manifest atypical clinical features. This intra-population venom variability contributes to the wider range of clinical manifestations of envenoming, including unusual clinical signs notably neurological features that are not typical of $V$. $b$. berus envenomings elsewhere in Europe.

\section{Acknowledgements}

We thank Dr Zoltán Korsós (Directorate of the Hungarian Natural History Museum, Budapest, Hungary) and Dr Ágnes Major Schrettné (Hungarian Natural History Museum, Molecular and Taxonomic Laboratory, Budapest, Hungary) the support of fieldwork by securing liquid nitrogen-can and liquid nitrogen. Thank you for providing the venom of Vipera nikolskii to Bálint Halpern (Budapest, Hungary). The Ministry of Water and Environmental Protection of Hungary issued the permit for $V$. berus venom collection.

\section{Conflict of interest statement}

The authors declare that there are no conflicts of interest.

\section{Literature}

1. Arez, A.P., Laing, G.D., do Rosario, V., Theakston, R.D.G., 1994. Preliminary studies on the characterization of venom from Vipera latastei latastei collected at NW of Portugal. Toxicon 4, 381-529.

2. Arikan, H., Göçmen, B., İğci, N., Akman, B., 2014. Age-dependent variations in the venom proteins of Vipera kaznakovi (Nikolsky, 1909) and Vipera ammodytes (Linnaeus, 1758) (Ophidia: Viperidae). Turk. J. Zool. 38, 216-221.

3. Balija, M.L., Vrdoljak, A., Habjanec, L., Dojnović, B., Halassy, B., Vranešić, B., Tomašić, J., 2005. The variability of Vipera ammodytes ammodytes venoms from Croatia - biochemical properties and biological activity. Comp. Biochem. Physiol. C 140, 257-263.

4. Blatt, N., 1923. Causes of the ocular disorders in snakebite envenoming. Zeitschrift für Augenheilkunde, 49, p. 280. [In German]

5. Bradford, M.M., 1976. A rapid and sensitive method for the quantitation of microgram quantities of protein utilizing the principle of protein-dye binding. Anal. Biochem. 72, 248-254.

6. Brown, J.H., 1973. Toxicology and pharmacology of venoms from poisonous snakes. Charles C. Thomas, Springfield. 
7. Calderón, L., Lomonte, B., Gutiérrez, J.M., Tarkowski, A., Hanson, L.A., 1993. Biological and biochemical activities of Vipera berus (European viper) venom. Toxicon 31, 743-754.

8. Casewell, N.R., Wagstaff, S.C., Wüster, W., Cook, D.A.N., Bolton, F.M.S., King, S.I., Pla, D., Sanz L., Calvete, J.J., Harrison, R.A., 2014. Medically important differences in sanke venom composition are dictated by distinct postgenomic mechanisms. PNAS 25, 9205-9210.

9. Chippaux, J.-P., Williams, V., White, J., 1991. Snake venom variability: methods of study, result and interpretation. Toxicon 11, 1279-1303.

10. de Haro, L., Glaizal, M., Tichadou, L., Blanc-Brisset, I., Hayek-Lanthois, M., 2009. Asp Viper (Vipera aspis) envenomation: Experience of the Marseille Poison Centre from 1996 to 2009. Toxins 1, 100-112.

11. Favreau, P., Menin, L., Michalet, S., Perret, F., Cheyneval, O., Stocklin, M., Bulet, P., Stocklin, R., 2006. Mass spectrometry strategies for venom mapping and peptide sequencing from crude venoms: case applications with single arthropod specimen. Toxicon 47, 676-687.

12. Ferquel, E., de Haro, L., Jan, V., Guillemin, I., Jourdain, S., Teynié, A., d'Alayer, J., Choumet, V., 2007. Reappraisal of Vipera aspis venom neurotoxicity. PloS ONE 11, $1-18$.

13. Gafencu, M., Doros, G., Badeti, R., Vasilie, D., 2012. Envenoming by Vipera berus: A case report of neurotoxicity. Clin. Toxicol. 4, p. 286. (EAPCCT Abstracts)

14. Guillemin, I., Bouchier, C., Garrigues, T., Wisner, A., Choumet, V., 2003. Sequences and structural organization of phospholipase $\mathrm{A}_{2}$ genes from $V$. aspis aspis, $V$. aspis zinnikeri, and Vipera berus berus venom. Identification of the origin of a new viper population based on ammodytin I1 heterogeneity. Eur. J. Biochem. 270, 2697-2706.

15. Harvey, A.L., Barfaraz, A., Thomson, E., Faiz, A., Preston, S., Harris, J.B., 1994. Screening of snake venoms for neurotoxic and myotoxic effects using simple in vitro preparations from rodents and chicks. Toxicon 3, 257-265.

16. Hasson, S.S., Theakston, R.D.G., Harrison, R.A., 2004. Antibody zymography: a novel adaptation of zymography to determine the protease-neutralising potential of specific antibodies and snake antivenoms. J. Immunol. 292, 131-139.

17. Jan, V.M., Guillemin, I., Robbe-Vincent, A., Choumet, V., 2007. Phospholipase $A_{2}$ diversity and polymorphism in European viper venoms: paradoxical molecular evolution in Viperinae. Toxicon 50, 1140-1161.

18. Križaj, I., Siigur, J., Samel, M., Cotic, V., Gubensek, F., 1993. Isolation, partial characterization and complete amino acid sequence of the toxic phospholipase $\mathrm{A}_{2}$ from venom of Vipera berus berus. Biochim. Biophys. Acta 1157, 81-85.

19. Laemmli, U.K., 1970. Cleavage of structural proteins during the assembly of the head of bacteriophage T4. Nature 227, 680-685.

20. Latinović, Z., Leonardi, A., Šribar, J., Sajevic, T., Žužek, M.C., Frangež, R., Halassy, B., Trampuš-Bakija, A., Pungerčar, J., Križaj, I. 2016. Venomics of Vipera berus berus to explain differences in pathology elicited by Vipera ammodytes ammodytes envenomation: Therapeutic implications. J. Proteomics 146, 34-47.

21. Magdalan, J., Trocha, M., Merwid-Ląd, A., Sozański, T., Zawadzki, M., 2010. Vipera berus bites in the region of Southwest of Poland - A clinical analysis of 26 cases. Wilderness Environ. Med. 21, 114-119.

22. Malenev, A.L., Bakiev, A.G., Zaytseva, O.V., Shurshina, I.V., 2007. Toxicity of the venom of the common adder from various spots of the area. Proceedings of the Samara scientific center RAN 1, 259-261. [In Russian] 
23. Malina, T., Krecsák, L., Warrell, D.A., 2008. Neurotoxicity and hypertension following European adder (Vipera berus berus) bites in Hungary: case report and review. QJM-Int. J. Med. 101, 801-806.

24. Malina, T., Babocsay, G., Krecsák, L., Erdész, Cs., 2013. Further clinical evidence for the existence of neurotoxicity in a population of the European adder (Vipera berus berus) in Eastern Hungary: second authenticated case. Wilderness Environ. Med. 24, 378-383.

25. Malta, M.B., Lira, M.S., Soares, S.L., Rocha, G.C., Knysak, I., Martins, R., Guizze, S.P.G., Santoro, M.L., Barbaro, K.C., 2008. Toxic activities of Brazilian centipede venoms. Toxicon 52, 255-263.

26. Master, R.W.P., Kornalik, F., 1965. Biochemical differences in yellow and white venoms of Vipera ammodytes and Russell's viper. J. Biol. Chem. 240, 139-142.

27. Mebs, D., Langelüdekke, T., 1992. European viper venoms haemorrhagic and myotoxic activities. Toxicon 10, 1303-1306.

28. Nedospasov, A.A., Rodina, E.V., 1992. Age changes of Vipera berus venom amidolytic activity. Toxicon 11, 1505-1508.

29. Nilson, G., Andrén, C., Völkl, W., 2005. Vipera (Pelias) berus (Linnaeus, 1758) Kreuzotter. In: Joger, U., Stümpel, N. (Eds.), Handbuch der Reptilien und Amphibien Europas, 3/IIB. Schlangen (Serpentes) III Viperidae. Aula Verlag, Wiesbaden, pp. 213-292. [In German]

30. Persson, H., 2015. Pathophysiology and treatment of envenomation by European vipers. In: Gopalakrishnakone, P., Faiz, M.A., Fernando, R., Gnanathasan, C.A., Habib, A.G., Yang, C.-C. (Eds.), Clinical Toxinology in Asia Pacific and Africa. Springer Netherlands, pp. 1-15.

31. Podani, J., 2001. SYN-TAX 2000. Computer programs for data analysis in ecology and systematics. User's manual. Scientia, Budapest. pp. 1-53.

32. Ramazanova, A.S., Zavada, L.L., Starkov, V.G., Kovyazina, I.V., Subbotina, T.F., Kostyukhina, E.E., Dementieva, I.N., Ovchinnikova, T.V., Utkin, Y.U., 2008. Heterodimeric neurotoxic phospholipase $\mathrm{A}_{2}$ - the first proteins from venom of recently established species Vipera nikolskii. Implication of venom composition in viper systematics. Toxicon 51, 524-537.

33. Saint Girons, H., Detrait, J., 1978. Communautés antigénique des venins et systématique des vipéres européennes. Étude immunoélectrophorétique. B. Soc. Zool. Fr. 103, 155-166. [In French]

34. Samel, M., Vija, H., Subbi, J., Siigur, J., 2003. Metalloproteinase with factor X activitaing and fibrinogenolytic activities from Vipera berus berus venom. Comp. Biochem. Physiol. B 135, 575-582.

35. Santoro, M.L., Sousa-e-Silva, M.C., Gonçalves, L.R., Almeida-Santos, S.M., Cardoso, D.F., Laporta-Ferreira, I.L., Saiki, M., Peres, C.A., Sano-Martins, I.S., 1999. Comparison of the biological activities in venoms from three subspecies of the South American rattlesnake (Crotalus durissus terrificus, $C$. durissus cascavella and $C$. durissus collilineatus). Comp. Biochem. Physiol. C 122, 61-73.

36. Schlereth, A., Becker, C., Horstmann, C., Tiedemann, J., Müntz, K., 2000. Comparison of globulin mobilization and cysteine proteinases in embryogenic axes and cotyledons during germination and seedling growth of vetch (Vicia sativa L.). J. Exp. Bot. 51, 1423-1433.

37. Strugariu, M.-C., Strugariu, A. 2014. Common adder (Vipera berus) bites in northeastern Romania: a retrospective analysis. 4th Biology of the Vipers Conference, Athens, Greece; 10-13 October 2014. Abstract Book. p. 28. (poster) 
38. Theakston, R.D.G., Reid, H.A., 1983. Development of simple standard assay procedures for the characterization of snake venoms. Bull. World Health Organ. 61, 949-956.

39. Ursenbacher, S., Carlsson, M., Helfer, V., Tegelström, H., Fumagalli, L., 2006. Phylogeography and Pleistocene refugia of the adder (Vipera berus) as inferred from mitochondrial DNA sequence data. Mol. Ecol. 15, 3425-3437.

40. Zaitseva, O.V., 2011. Population related venom characteristics of the adder, Vipera berus (Linnaeus, 1758) in the Volga basin. Thesis for the the degree of Candidate of Biological Sciences. pp. 1-24. Togliatti, 2011. [In Russian]

\section{Tables:}

Table 1. Data of snakes and the molecular mass peaks in the range of PLA 2 s (13000-15000 $\mathrm{Da}$ ) detected in their venoms by MALDI-TOF-MS. Underlined components are the common components present in the individual venoms.

Legend: $\mathrm{F}=$ female; $\mathrm{M}=$ male; *= not recorded; $\mathrm{A}=$ adult $(58.3-77.4 \mathrm{~cm}) ; \mathrm{Sa}=$ Subadult $(42.5-50.7 \mathrm{~cm}) ; \mathrm{J}=\mathrm{Juvenile}$ $(16.2-36.7 \mathrm{~cm})$

\begin{tabular}{|c|c|c|c|c|}
\hline $\begin{array}{c}\text { Specimen } \\
\text { number } \\
\text { on SDS- } \\
\text { PAGE gel }\end{array}$ & Sex & $\begin{array}{l}\text { age- } \\
\text { group }\end{array}$ & $\begin{array}{l}\text { Total } \\
\text { length } \\
\text { in } \mathrm{cm}\end{array}$ & Mass peaks in Da \\
\hline 1 & $\bar{F}$ & $\mathrm{Sa}$ & 48.3 & $\underline{13571.78}, \underline{13680.64}, \underline{13889.81}, \underline{14098.17}, 14200.50$ \\
\hline 2 & $\mathrm{~F}$ & A & 70 & $13587.57,13705.36,13914.09,14117.50,14315.69$ \\
\hline 3 & M & $\mathrm{Sa}$ & 45 & $13558.84, \underline{13677.66}, \underline{13886.53}, \underline{14098.00}, 14307.13$ \\
\hline 4 & $\mathrm{~F}$ & A & 66 & $\overline{13548.35}, \underline{13665.44}, \underline{13875.59}, \underline{13984.77}, 14091.58,14282.36$ \\
\hline 5 & M & A & 58.3 & $\underline{13555.81}, \underline{13679.11}, \overline{13878.40}, \overline{14085.41}$ \\
\hline 6 & M & $\mathrm{Sa}$ & 43.3 & $\frac{13571.10}{14107.32}, \underline{13682.39}, 13770.59, \underline{13889.30}, 13951.32,13988.96$, \\
\hline 7 & $\mathrm{~F}$ & $\mathrm{~J}$ & 28.1 & $13563.24, \underline{13682.02}, \underline{13892.11}, 14106.38$ \\
\hline 8 & M & $\mathrm{J}$ & 22 & $13556.07, \underline{13672.19}, 13875.66,14100.02$ \\
\hline 9 & M & $\mathrm{J}$ & 16.2 & $\overrightarrow{13559.24}, \overrightarrow{13676.09}, \overline{13885.18}, 13986.22, \underline{14096.58}$ \\
\hline 10 & $\mathrm{~F}$ & $\mathrm{~J}$ & 26.3 & $13565.25, \underline{13687.35}, 13893.93,14101.97$ \\
\hline 11 & M & A & 60.1 & $\underline{13587.67}, \overline{13724.53}, \overline{13916.70}, \underline{14121.61}, 14322.08$ \\
\hline 12 & M & $\mathrm{Sa}$ & 42.5 & $\overline{13678.27}, 13700.65,13909.08, \overline{14022.63}, 14121.96,14340.17$ \\
\hline 13 & $\mathrm{~F}$ & A & 61 & $13558.54,13677.21,13889.11,13996.17, \underline{14098.99}$ \\
\hline 14 & $\mathrm{~F}$ & A & 77.4 & $13555.52,13672.64, \overline{13880.36}, 13941.70, \overline{14096.62}$ \\
\hline 15 & M & $\mathrm{Sa}$ & 43.8 & $\underline{13556.07}, 13671.17, \underline{13880.43}, \underline{13984.55}, 14097.37,14299.47$ \\
\hline 16 & $\mathrm{~F}$ & A & 59.8 & $13557.77,13674.76,13887.55, \underline{14102.12}, 14305.42$ \\
\hline 17 & M & $\mathrm{Sa}$ & 50.7 & $\frac{13555.48}{14291.53}, \underline{13665.77}, 13874.31,13955.67,13971.57,14084.54$ \\
\hline 18 & $\mathrm{~F}$ & $\mathrm{Sa}$ & 44.9 & $13567.79,13684.87, \underline{13897.19}, 14109.43,14320.71$ \\
\hline 19 & $\mathrm{~F}$ & $\mathrm{Sa}$ & 47.6 & $\underline{13555.49}, 13673.5, \underline{13886.89}, 13993.27, \underline{14102.59}, 14304.03$ \\
\hline 20 & $\mathrm{~F}$ & A & 73.8 & $13571.77, \underline{13687.30}, \underline{13897.15}, \underline{14004.33}, 14112.52,14323.60$ \\
\hline 21 & $\mathrm{~F}$ & A & 70.1 & $13554.91,13680.77,13892.89,14004.91,14104.44,14311.49$ \\
\hline 22 & M & $\mathrm{J}$ & 36.7 & $13561.72, \underline{13677.41}, \underline{13886.73}, 14018.60, \underline{14094.54}$ \\
\hline 23 & M & A & 60.2 & $13549.18, \underline{13665.87}, 13877.13,13987.37, \underline{14093.40}, 14302.66$ \\
\hline 24 & $\mathrm{~F}$ & $\mathrm{Sa}$ & 48.1 & $\underline{13555.61}, \underline{13672.42}, \underline{13880.38}, \underline{14093.70}$ \\
\hline 25 & $\mathrm{~F}$ & A & 69.7 & $13562.91,13679.42,13891.32,13998.02,14105.52,14310.11$ \\
\hline $\begin{array}{l}\text { Austrian } \\
V . b . \text { berus }\end{array}$ & $*$ & A & * & $13550.03, \overline{13678.21}, \underline{13893.63}, \underline{14094.04}, 14283.2$ \\
\hline V. nikolskii & $*$ & A & $*$ & $13654.60,13842.53,14043.29$ \\
\hline
\end{tabular}


Table 2. Case reports about neurotoxic envenomings by $V . b$. berus in the Carpathian basin, published so far in the scientific and/or medical literature.

Legend: $\mathrm{F}=$ female; $\mathrm{M}=$ male; *= Malina et al. (2008) re-mentioned Széll's data, reported in 1878. **= Malina et al. (2008) noted Petraskó's data, recorded in 1899 . ***=In this case, the taxon was erroneously recorded as Vipera berus bosniensis by the authors because only the nominate subspecies of the adder $(V . b$. berus $)$ occurs in Romania (Ursenbacher et al., 2006).

\begin{tabular}{|c|c|c|c|c|c|}
\hline Author & $\begin{array}{l}\text { Year of } \\
\text { incident }\end{array}$ & Locality of incident & $\begin{array}{l}\text { age of } \\
\text { patient }\end{array}$ & $\begin{array}{l}\text { sex of } \\
\text { patient }\end{array}$ & $\begin{array}{c}\text { recorded cranial nerve } \\
\text { disturbances }\end{array}$ \\
\hline $\begin{array}{l}\text { Malina et al. } \\
(2008)^{*}\end{array}$ & 1878 & western Transylvania & 24 years & $\mathrm{M}$ & $\begin{array}{l}\text { bilateral ptosis, } \\
\text { blindness }\end{array}$ \\
\hline $\begin{array}{l}\text { Malina et al. } \\
(2008)^{* *}\end{array}$ & 1895 & western Transylvania & 43 years & $\mathrm{F}$ & ophthalmoplegia \\
\hline Blatt (1923) & 1922 & Transylvania & 40 years & $\mathrm{F}$ & $\begin{array}{c}\text { accommodation trouble, } \\
\text { ophthalmoplegia, } \\
\text { bilateral } \\
\text { ptosis }\end{array}$ \\
\hline $\begin{array}{l}\text { Malina et al. } \\
\text { (2008) }\end{array}$ & 2007 & eastern Hungary & 27 years & M & $\begin{array}{c}\text { diplopia, } \\
\text { ophthalmoplegia }\end{array}$ \\
\hline $\begin{array}{l}\text { Gafencu et al. } \\
(2012) * * *\end{array}$ & $\begin{array}{c}\text { not } \\
\text { mentioned }\end{array}$ & $\begin{array}{l}\text { south-western } \\
\text { Romania }\end{array}$ & 14 years & $\mathrm{F}$ & $\begin{array}{l}\text { blurred vision, bilateral } \\
\text { ptosis, dysphagia }\end{array}$ \\
\hline $\begin{array}{l}\text { Strugariu and } \\
\text { Strugariu } \\
\text { (2014) }\end{array}$ & $2003-2011$ & $\begin{array}{l}\text { north-eastern } \\
\text { Romania }\end{array}$ & 9 years & $\mathrm{F}$ & bilateral ptosis \\
\hline $\begin{array}{l}\text { Malina et al. } \\
(2013)\end{array}$ & 2012 & eastern Hungary & 12 years & $\mathrm{F}$ & $\begin{array}{c}\text { bilateral but partial } \\
\text { ptosis, gaze paresis, } \\
\text { diplopia }\end{array}$ \\
\hline
\end{tabular}




\section{Figure captions:}

Figure 1. (A) SDS-PAGE photograph of the complete venom pattern (under non-reduced conditions) of the adders used in this study and (B) the cluster analysis of the grouped electrophoretic results.

Legend on A): $\mathrm{M}=$ marker; Samples from 1 to $25=$ Hungarian $V$. b. berus; $26=\mathrm{Aus} V \mathrm{bb}=\mathrm{Austrian} V$. b. berus; $27=$ Vnik $=V$. nikolskii; $\mathrm{A}=$ adult specimen; $\mathrm{Sa}=$ subadult specimen; $\mathrm{J}=\mathrm{juvenile;} \hat{\delta}=$ =male; $\mathrm{Q}=$ =female

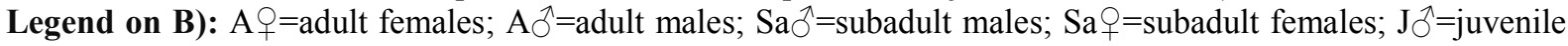
males; $\mathrm{J}$ + $=$ juvenile females; AusVbb=Austrian $V$. b. berus specimen; Vnik $=V$. nikolskii specimen

Figure 2. Representative spectra of the $\mathrm{PLA}_{2}$ content of individual venoms in case of the Hungarian $V . b$. berus specimens and the two control venoms by MALDI-TOF MS (dimers are not shown). Spectrum represents four experiments in each case. Samples from the same specimens are presented with the same number as in figure 1.

Legend: Molecular mass (in Da) is given each peak for each component present. $\mathrm{Y}$ axis is the intensity and $\mathrm{X}$ the molecular masses. Samples from the same specimens are presented with the same number as in figure 2 .

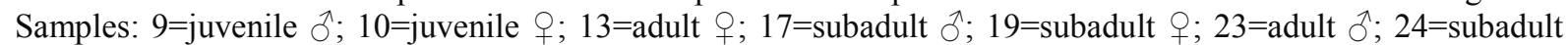
क; $26=$ Austrian $V$. b. berus; $27=\mathrm{V}$. nikolskii

Figure 3. Substrate zymography of the venoms from the eastern Hungarian adders and the two control venoms on gelatine substrate. Enzymatic activity of the samples is indicated by the clear degradations (plaques) on the gel. Molecular mass markers (in kDa) are indicated at the left of the gels. Samples from the same specimens are presented with the same number as in figure 1.

Legend: $M=$ marker. Arrows with the numbers correspond to the position of molecular mass markers (M). $\mathrm{A}=$ adult specimen; $\mathrm{Sa}=$ subadult specimen; $\mathrm{J}=$ juvenile; $\hat{\delta}=$ male; $\mathrm{Q}=$ female; AusVbb=Austrian $V$. b. berus specimen; Vnik=V. nikolskii specimen.

Figure 4. $\mathrm{LD}_{50}$ values of the Hungarian $V$. b. berus individual venoms and the two controls. (A): pairwise relative potency comparison and between the venom samples $(*=$ significant difference, values in parenthesis are represented the $95 \%$ confidence limits). (B): LD 50 values of the tested samples. Samples from the same specimens are presented with the same number as in figure 1.

Figure 5. Neuromuscular effects of venoms on chick biventer cervicis nerve-muscle preparations. Samples from the same specimens are presented with the same number as in figure 1 .

Legend: (A) and (C): time and concentration dependent inhibition of indirectly-stimulated twitch contractions by venoms. (B), (D) and (E): contractile responses of preparations to the exogenous acetylcholine (ACh), carbachol (Car) and potassium chloride $(\mathrm{KCl})$ after complete inhibition of the nerve-evoked twitches. (F): lasted time to $50 \%$ twitch block on preparations. Sample 26 (Aus Vbb) was available only in a smaller amount.

$\mathrm{A}=$ adult; $\mathrm{Sa}=$ subadult; $\mathrm{J}=\mathrm{juvenile} \mathrm{specimen;} \mathrm{Aus} \mathrm{Vbb}=$ Austrian $V$. b. berus; $\mathrm{Vnik}=V$. nikolskii 